\title{
The Proinflammatory Cytokine Interleukin 18 Regulates Feeding by Acting on the Bed Nucleus of the Stria Terminalis
}

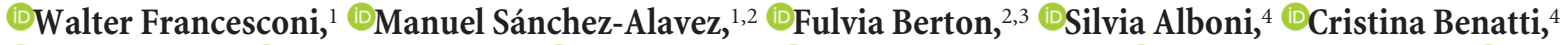

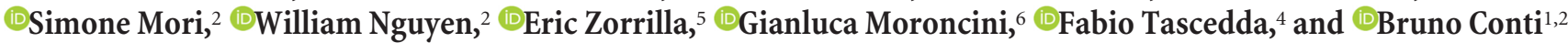 \\ ${ }^{1}$ Molecular and Cellular Neuroscience Department and ${ }^{2}$ Department of Chemical Physiology, and ${ }^{5}$ CNAD, The Scripps Research Institute, La Jolla, \\ California, ${ }^{3}$ Department of Biology, University of Pisa, Italy, ${ }^{4}$ Department of Life Sciences, Universita degli Studi di Modena e Reggio Emilia, Modena, Italy, \\ and ${ }^{6}$ Dipartimento di Scienze Cliniche e Molecolari, Università Politecnica delle Marche, Ancona, Italy
}

The proinflammatory cytokine IL-18 has central anorexigenic effects and was proposed to contribute to loss of appetite observed during sickness. Here we tested in the mouse the hypothesis that IL-18 can decrease food intake by acting on neurons of the bed nucleus of the stria terminalis (BST), a component of extended amygdala recently shown to influence feeding via its projections to the lateral hypothalamus (LH). We found that both subunits of the heterodimeric IL-18 receptor are highly expressed in the BST and that local injection of recombinant IL-18 (50 ng/ml) significantly reduced c-fos activation and food intake for at least $6 \mathrm{~h}$. Electrophysiological experiments performed in BST brain slices demonstrated that IL-18 strongly reduces the excitatory input on BST neurons through a presynaptic mechanism. The effects of IL-18 are cell-specific and were observed in Type III but not in Type I/II neurons. Interestingly, IL-18-sensitve Type III neurons were recorded in the juxtacapsular BST, a region that contains BST-LH projecting neurons. Reducing the excitatory input on Type III GABAergic neurons, IL-18 can increase the firing of glutamatergic LH neurons through a disinhibitory mechanism. Imbalance between excitatory and inhibitory activity in the LH can induce changes in food intake. Effects of IL-18 were mediated by the IL-18R because they were absent in neurons from animals null for IL-18R $\alpha$ (Il18ra $\left.{ }^{-/-}\right)$, which lack functional IL-18 receptors. In conclusion, our data show that IL-18 may inhibit feeding by inhibiting the activity of BST Type III GABAergic neurons.

Key words: bed nucleus of the stria terminalis; cytokine; feeding; inflammatory; interleukin 18; sickness

Significance Statement

Loss of appetite during sickness is a common and often debilitating phenomenon. Although proinflammatory cytokines are recognized as mediators of these anorexigenic effects, their mechanism and sites of action remain poorly understood. Here we show that interleukin 18, an anorexigenic cytokine, can act on neurons of the bed nucleus of the stria terminalis to reduce food intake via the IL-18 receptor. The findings identify a site and a mode of action that indicate targets for the treatment of cachexia or other eating disorders.

\section{Introduction}

Illness is typically associated with several nonspecific symptoms, such as fever, sleepiness, anxiety, loss of appetite, and depression, which are collectively referred to as sickness syndrome (Konsman

Received Oct. 26, 2015; revised March 31, 2016; accepted April 4, 2016.

Author contributions: W.F., F.B., and B.C. designed research; W.F., M.S.-A., F.B., S.A., C.B., S.M., and W.N. performed research; W.F., M.S.-A., S.A., E.Z., and B.C. analyzed data; W.F., M.S.-A., S.A., E.Z., G.M., F.T., and B.C. wrote the paper.

This work was supported by National Institute of Neurological Disorders and Stroke Grant NS085155 and National Institute of Diabetes and Digestive and Kidney Diseases Grant DK094026. We thank Sheila Silverstein for editing this manuscript.

The authors declare no competing financial interests.

Correspondence should be addressed to either Dr. Walter Francesconi or Dr. Bruno Conti, Molecular and Cellular Neuroscience Department, The Scripps Research Institute, 0550 North Torrey Pines Road, La Jolla, CA 92037. E-mail: wfranc@scripps.edu or bconti@scripps.edu.

DOI:10.1523/JNEUROSCI.3919-15.2016

Copyright $\odot 2016$ the authors $\quad 0270-6474 / 16 / 365170-11 \$ 15.00 / 0$ et al., 2002; Kelley et al., 2003). Sickness syndrome is recognized to be, at least, in part, mediated by cytokines produced during infections or tissue damage, but the exact mechanisms by which this occurs are not entirely understood.

Interleukin 18 (IL-18) is a pleiotropic proinflammatory cytokine whose levels increase during or following infection. IL-18 is produced by different cell types in the periphery; and centrally it is present in microglia, ependymal cells, and neurons of the medial habenula (Alboni et al., 2009, 2010, 2011). We and others previously provided evidence that IL-18 may regulate energy homeostasis by suppressing appetite and increasing metabolic rate (Netea et al., 2006; Zorrilla et al., 2007; Zorrilla and Conti, 2014; Hale et al., 2015). Mice null for IL-18 are hyperphagic, show reduced energy expenditure, and eventually become obese and develop insulin resistance. Consistently, intracerebroventricular administration of IL-18 had anorexigenic effects. We also identi- 
fied two subunits of the IL- 18 receptor (IL-18R $\alpha$ and IL-18R $\beta$ ) in the mouse brain (Alboni et al., 2009, 2011). One region with IL-18R $\alpha$ and IL-18R $\beta$ expression was the anterodorsal division of the bed nucleus of the stria terminalis (adBST).

The adBST is an important multinucleated component of the extended amygdala circuitry that can be anatomically and functionally subdivided into two dorsal subregions: the anterolateral BST (alBST) and the anteromedial BST. The alBST contains the oval (ovBST) and the juxtacapsular nucleus (jcBST) and is interconnected with regions that subserve stress and reward, including the amygdala, lateral hypothalamus (LH), ventral tegmental area, and NAc (Choi and Lovinger, 1997; Aston-Jones and Druhan, 1999; Georges and Aston-Jones, 2001; Georges and Aston-Jones, 2002; Funk et al., 2006; Sahuque et al., 2006; Shepard et al., 2006; Lee et al., 2008; Jalabert et al., 2009; Davis et al., 2010; Gafford et al., 2012; Kim et al., 2013; Sink et al., 2013; Micioni Di Bonaventura et al., 2014; Gafford and Ressler, 2015). The vast majority (70\%-90\%) of adBST neurons are composed of medium-sized spiny GABAergic neurons (McDonald, 1983; Sun and Cassell, 1993; Hazra et al., 2011). In addition, the only neurons expressing vesicular glutamate transporters (VGLUT2) were observed in the posterior divisions of the BST (interfascicular and ventral nuclei). None was found in the anterolateral, magnocellular, and rhomboid nucleus or in the oval, juxtacapsular nucleus (Poulin et al., 2009). Perhaps accordingly, the adBST is emerging as an important regulator of feeding behavior. Corticotropin releasing factor receptors in the adBST are involved in feeding behavior during stress (Ciccocioppo et al., 2003; Ohata and Shibasaki, 2011; Micioni Di Bonaventura et al., 2014). Elegant work from Jennings et al. (2013) suggests that this action is mediated, in part, by the modulation of inhibitory projections that the adBST sends to the LH. Specifically, optogenetic activation of GABAergic neurons in the BST stimulated marked eating in well-fed animals.

The adBST contains at least three different functional types of neurons that can be distinguished by the presence and amount of specific voltage-gated ionic conductances (Hammack et al., 2007; Szücs et al., 2010). Of these, Type I and Type II neurons are sparsely distributed in the alBST and in the ovBST, whereas the Type III neurons are highly concentrated along the internal capsule, in the jcBST (Rodríguez-Sierra et al., 2013). These neuronal types appear to be differentially involved in stress-induced plasticity of synaptic and intrinsic neural properties. For instance, LTP of EPSCs induced in Type I, II, and III adBST neurons was selectively increased only in Type III neurons after repeated restraint stress (Dabrowska et al., 2011). The three types of BST neurons are also differentially influenced by prolonged alcohol withdrawal, during which the hyperpolarization-activated cation (Ih) current of Type II neurons in the jcBST was significantly reduced, whereas the Ih current in Type I was unaltered (Szücs et al., 2012).

Here we tested the hypothesis that one of the mechanisms by which IL-18 may regulate feeding centrally is via its action on the BST and characterized by its effects on Type I, II, and III neurons therein.

\section{Materials and Methods}

Animals and treatments. All experiments were done on 3- to 5-month-old male Il18 $\mathrm{ra}^{-/-}$or wild-type littermate mice on a C57BL6 background. Animals were housed in polycarbonate cages $(28 \times 17 \times 12 \mathrm{~cm})$ with ad libitum access to food and water throughout the study and maintained on a light-dark cycle of 12/12 h with lights on from 6:00 A.M. to 6:00 P.M., in an ambient temperature of $21 \pm 3^{\circ} \mathrm{C}$ with relative humidity controlled.
All procedures were approved by the Institutional Animal Care and Use Committee of the Scripps Research Institute and were done in accordance with the National Institutes of Health's Guide for the care and use of laboratory animals, the EC guidelines (EEC Council Directive, 2010/63/ $\mathrm{UE}$ ), and Italian legislation on animal experimentation (Decreto Legislativo 26/2014). Mice receiving injections of recombinant IL-18 or vehicle were implanted with cannulas as previously described (SánchezAlavez et al., 2007, 2010). Briefly, under isoflurane anesthesia (induction $3 \%-5 \%$, maintenance $1 \%-1.5 \%$ ), two holes were drilled bilaterally in the skull through which cannulas were inserted bilaterally into the BST with the following stereotactic coordinates (final infusion coordinates anterior-posterior from bregma $0.14 \mathrm{~mm}$, lateral $\pm 0.9 \mathrm{~mm}$, ventral $-4.3 \mathrm{~mm}$, cannula 26 gauge, $7 \mathrm{~mm}$ length) and fixed to an anchor screw with dental cement. In addition, mice were implanted with telemetry devices (TAF10; Data Sciences) in the peritoneal cavity for core body temperature and locomotor activity measurement.

For studies investigating the anorexigenic effects of IL-18, mice were food-deprived overnight for $17 \mathrm{~h}$ before receiving bilateral microinjections (volume, $0.2 \mu \mathrm{l})$ of IL-18 ( $0.34 \mathrm{nmol} /$ mouse) or vehicle (aCSF; 126 mм NaCl, $3.5 \mathrm{~mm} \mathrm{KCl}, 2 \mathrm{~mm} \mathrm{CaCl}_{2}, 1 \mathrm{~mm} \mathrm{MgSO}_{4}, 1.25 \mathrm{~mm} \mathrm{NaH}_{2} \mathrm{PO}_{4}, 26$ $\mathrm{mm} \mathrm{NaHCO}$, and $10 \mathrm{~mm}$ glucose, $\mathrm{pH}$ 7.4) into the BST through the implanted cannulas. Infusate was injected over $2 \min ($ rate $0.1 \mu \mathrm{l} / \mathrm{min}$ ), allowing $2 \mathrm{~min}$ for diffusion via a Hamilton microsyringe ( $5 \mu \mathrm{l})$ linked by PE 10 tubing to a 33-gauge injector. At $5 \mathrm{~min}$ after microinjection into the BST, mice were refed (at Zeitberger time 128 4, ZT4). Remaining food was measured $1,3,6,7$, and $24 \mathrm{~h}$ after injection. The dose was chosen based on our earlier ventricle work (Zorrilla et al., 2007). Placement of cannulas was confirmed postmortem under light microscopy following $2 \%$ Evans Blue infusion $(0.2 \mu \mathrm{l})$. Recombinant endotoxin-free mouse IL-18 was obtained commercially (BioSource International; MBL International) and dissolved in aCSF. Food intake and indirect calorimetry were performed in acclimated, singly housed, standard diet-fed mice (Harlan Teklad LM-485 Diet 7012; 58\% carbohydrate, 17\% fat, metabolizable energy $3.1 \mathrm{kcal} / \mathrm{g}$ ) using a computer-controlled open-circuit system (Oxymax System) that is part of an integrated Comprehensive Laboratory Animal Monitoring System (Columbus Instruments). Animals were tested in clear respiratory chambers equipped with a food tray connected to a balance that measures food weight. Room air is passed through chambers at a flow rate of $\sim 0.5 \mathrm{l} / \mathrm{min}$. Exhaust air from each chamber is sampled at $30 \mathrm{~min}$ intervals for $1 \mathrm{~min}$. Sample air is sequentially passed through $\mathrm{O}_{2}$ and $\mathrm{CO}_{2}$ sensors (Columbus Instruments) for determination of $\mathrm{O}_{2}$ and $\mathrm{CO}_{2}$ content, from which measures of oxygen consumption $\left(\mathrm{VO}_{2}\right)$ and carbon dioxide production $\left(\mathrm{VCO}_{2}\right)$ are estimated. Gas sensors are calibrated before the onset of experiments with primary gas standards containing known concentrations of $\mathrm{O}_{2}, \mathrm{CO}_{2}$, and $\mathrm{N}_{2}$ (Airgas Puritan Medical). Respiratory exchange ratio (RER) is calculated as the ratio of $\mathrm{VCO}_{2}$ to $\mathrm{VO}_{2}$. Energy expenditure measures $\left(\mathrm{VO}_{2}\right.$, $\mathrm{VCO}_{2}$, and heat formation $\left[\{3.815+1.232 \times \mathrm{RER}\} \times \mathrm{VO}_{2}\right.$ \{in liters $\left.\left.\}\right]\right)$ are corrected for estimated effective metabolic mass per Kleiber power function. Mice undergoing indirect calorimetry were acclimated to the respiratory chambers for 3-4 d before the onset of the study.

In situ hybridization. Analysis of IL- $18 \mathrm{R} \alpha$ and IL- $18 \mathrm{R} \beta \mathrm{mRNAs}$ distribution in the BST was performed by nonisotopic ISH using a specific digoxigenin (DIG)-labeled antisense riboprobe and a sense probe as negative control. cDNA [nt 1574-1960 (accession no. NM_008365)] for mouse IL-18R $\alpha$ and [nt 759-1137 (NCBI GenBank accession number: NM_010553)] mouse IL-18R $\beta$ were subcloned into pDrive Cloning Vector (QIAGEN) to obtain a template for the in vitro transcription of cRNAs [antisense (using BamH I restriction site); sense (using HindIII restriction site)] as previously described (Alboni et al., 2009, 2011). Probes (antisense [AS] and sense [S]) to be used in ISH assay were synthesized using the DIG-RNA labeling kit (La Roche Diagnostics) according to the manufacturer's instructions (SP6 polymerase for AS probe; T7 polymerase for $\mathrm{S}$ probe). For ISH, mice were anesthetized by isoflurane inhalation and perfused transcardially with heparinized (5.000 IU/L) saline followed by perfusion with ice-cold $4 \%$ PFA in PBS, pH 7.4. After fixation, brains were rapidly removed and postfixed overnight in the same fixative solution, and then cryoprotected in a $30 \%$ sucrose solution in phosphate buffer, $\mathrm{pH}$ 7.4. Brains were cut coronally in $40 \mu \mathrm{m}$ serial 
sections by a cryostat, collected in diethylpyrocarbonate (DEPC)-PBS $1 \times$ and washed 2 times ( 5 min each) in fresh DEPC-PBS $1 \times$. Free floating sections were then treated 2 times ( 5 min each) with DEPC-treated PBS containing $100 \mathrm{~mm}$ glycine and then with DEPC-treated PBS containing $0.3 \%$ Triton $\mathrm{X}-100$ ( $15 \mathrm{~min}$ ). After washing 2 times ( 5 min each), sections were permeabilized at $37^{\circ} \mathrm{C}(10 \mathrm{~min})$ with TE buffer $(100 \mathrm{~mm}$ Tris- $\mathrm{HCl}, 50 \mathrm{~mm}$ EDTA, pH 8) containing $1 \mu \mathrm{g} / \mathrm{ml}$ RNase-free Proteinase $\mathrm{K}$. Sections were postfixed $(5 \mathrm{~min})$ at $4^{\circ} \mathrm{C}$ with DEPC-treated PBS containing 4\% PFA, washed 2 times ( 5 min each) with DEPC-treated PBS, and acetylated 2 times (5 min each) with $0.1 \mathrm{~m}$ triethanolamine buffer, $\mathrm{pH} 8$, containing $0.25 \%[\mathrm{v} / \mathrm{v}]$ acetic anhydride. Sections were then prehybridized at least $30 \mathrm{~min}$ at $37^{\circ} \mathrm{C}$ in prehybridization buffer $(4 \times$ SSC containing 50\% [v/v] deionized formamide; $1 \times$ SSC: $150 \mathrm{~mm}, 9 \mathrm{NaCl}, 15$ mu sodium citrate, $\mathrm{pH} 7.2$ ) and incubated overnight at $58^{\circ} \mathrm{C}$ for Type I IL- $18 \mathrm{R} \alpha$ or $52^{\circ} \mathrm{C}$ for IL-18R $\beta$ mRNA in hybridization buffer containing $40 \%$ deionized formamide, $10 \%$ dextran sulfate, $1 \times$ Denhardt's solution [0.02\% Ficoll, $0.02 \%$ polyvinylpyrrolidone, $0.2 \mathrm{mg} / \mathrm{ml}$ RNase free BSA], $4 \times$ SSC, $10 \mathrm{~mm}$ DTT, $1 \mathrm{mg} / \mathrm{ml}$ yeast t-RNA, $1 \mathrm{mg} / \mathrm{ml}$ denaturated and sheared salmon sperm DNA, and $30 \mathrm{ng}$ /slice of DIG-labeled RNA sense or antisense probe. After hybridization, the sections were washed 2 times (15 min each) at $50^{\circ} \mathrm{C}$ in $2 \times$ SSC containing $50 \%$ [v/v] deionized formamide (only for Type I IL- $18 \mathrm{R} \alpha$ ), 2 times ( $15 \mathrm{~min}$ each) at $50^{\circ} \mathrm{C}$ in $2 \times \mathrm{SSC}$, 2 times $(15 \mathrm{~min}$ each $)$ at $50^{\circ} \mathrm{C}$ in $1 \times \mathrm{SSC}, 1$ times $(15 \mathrm{~min})$ at $50^{\circ} \mathrm{C}$ in $0.25 \times \mathrm{SSC}, 1$ time $(15 \mathrm{~min})$ at $37^{\circ} \mathrm{C}$ in $0.25 \times \mathrm{SSC}$, and 2 times $(30 \mathrm{~min}$ each) at $37^{\circ} \mathrm{C}$ in $0.1 \times$ SSC. After 2 washes of 10 min each in Buffer $1(100$ mm Tris- $\mathrm{HCl}, \mathrm{pH} 7.5,150 \mathrm{~mm} \mathrm{NaCl}$ ), sections were preincubated in blocking solution (Buffer 1 containing $0.1 \%$ Triton X-100 and 2\% normal goat serum). For detection of DIG, sections were incubated overnight at $4^{\circ} \mathrm{C}$ in $1 \%$ normal goat serum-blocking solution containing anti-DIG alkaline phosphatase (Fab fragment) diluted 1:400 (La Roche Diagnostics). Subsequently, sections were washed 2 times (10 min each) in Buffer 1 followed by a washing in Buffer 2 (100 mм Tris-HCl, pH 9.5, $100 \mathrm{~mm} \mathrm{NaCl}, 50 \mathrm{~mm} \mathrm{MgCl}$ ). The chromogenic reaction was performed for $1-3 \mathrm{~h}$ at room temperature in the dark using a solution $(100 \mathrm{~mm}$ Tris- $\mathrm{HCl}, \mathrm{pH} 9.5,100 \mathrm{~mm} \mathrm{NaCl}$ ) containing nitroblue tetrazolium and 5-bromo-4-chloro-3-indolyl-phosphate and $1 \mathrm{~mm}$ levamisole. The color reaction was stopped by incubating sections in Buffer $3(10 \mathrm{~mm}$ Tris- $\mathrm{HCl}$, $\mathrm{pH} 8,1 \mathrm{~mm}$ EDTA, $\mathrm{pH}$ 8) for several hours. Images were acquired through a digital AxioCam HRc color camera mounted on an AxioScope 40 (Zeiss) using the AxionVision program.

c-fos immunostaining. Immunostaining was performed on brain sections prepared as described for in situ hybridization from brains of animals food-deprived overnight for $17 \mathrm{~h}$ before receiving bilateral microinjection of IL-18 or vehicle as described for feeding experiments. Tissue was collected $3 \mathrm{~h}$ after IL-18 administration. Free-floating sections containing the regions of interest were washed several times in $0.1 \mathrm{M}$ phosphate buffer $(\mathrm{PB})$ and then permeabilized in $0.3 \%$ Triton $\mathrm{X}-100$ in $0.1 \mathrm{M}$ PB for $1 \mathrm{~h}$. Sections were blocked in 5\% normal goat serum, $1 \%$ BSA, $0.3 \%$ Triton X-100 in 0.1 м PB for $1 \mathrm{~h}$ at room temperature. Sections were incubated with c-fos rabbit polyclonal IgG (sc-52; Santa Cruz Biotechnology) at 1:2000 in diluent of blocking buffer at $4^{\circ} \mathrm{C}$ overnight gently shaking. After multiple washes in $0.5 \%$ BSA in $0.1 \mathrm{M} \mathrm{PB}$, fluorescent labeling was performed through incubation with Goat anti-Rabbit IgG $(\mathrm{H}+\mathrm{L})$ Secondary Antibody (AlexaFluor-594 conjugate, A-11012; Invitrogen) diluted $1: 250$ in $0.5 \%$ BSA, $0.3 \%$ Triton X-100 in $0.1 \mathrm{M} \mathrm{PB.}$ After $2 \mathrm{~h}$ incubation at room temperature, sections were washed and counterstained with DAPI (D1306, Thermo Fisher); sections were mounted on Southern Biotechnology Fluoromount-G Slide Mounting Medium, coverslipped, and kept at $4^{\circ} \mathrm{C}$. Images were taken on a Zeiss LSM 710 laser scanning confocal microscope and analyzed with the Zen Blue 2015 (Zeiss) software.

Electrophysiology. Whole-cell patch-clamp recordings were performed from 50 physiologically identified Type III and Type I/II neurons located in the adBST. We usually recorded 2 neurons from each mouse brain. Briefly, BST slices $(350 \mu \mathrm{M})$ were collected in oxygenated sucrose-base aCSF (in mM) as follows: 206 sucrose, $2.5 \mathrm{KCl}, 0.5 \mathrm{CaCl}_{2}, 7 \mathrm{MgCl}_{2}, 26$ $\mathrm{NaHCO}_{3}, 1.20 \mathrm{NaH}_{2} \mathrm{PO}_{4}, 5$ D-glucose, and 5 HEPES. Slices were then preincubated for at least $1 \mathrm{~h}$ in aCSF containing (in mM) as follows: 124 $\mathrm{NaCl}, 10 \mathrm{HEPES}, 2 \mathrm{KCl}, 2 \mathrm{CaCl}_{2}, 2 \mathrm{MgSO}_{4} \cdot 7 \mathrm{H}_{2} \mathrm{O}, 26 \mathrm{NaHCO}_{3}, 1.25$
$\mathrm{KH}_{2} \mathrm{PO}_{4}, 10$ D-glucose, $\mathrm{pH} 7.4$, at $30^{\circ} \mathrm{C}$ (osmolarity 290-300 mOsm). For electrophysiological recording, slices were transferred to a submerged recording chamber, perfused at the rate of $2 \mathrm{ml} / \mathrm{min}$ with oxygenated aCSF at $30 \pm 1{ }^{\circ} \mathrm{C}$. AMPA-mediated responses were pharmacologically isolated by adding to the aCSF APV $(50 \mu \mathrm{M})$ and (+)bicuculline $(60 \mu \mathrm{M})$ to block NMDA and $\mathrm{GABA}_{\mathrm{A}}$ receptors, respectively. The $\mathrm{GABA}_{\mathrm{B}}$ receptors were blocked by adding SCH $50911(20 \mu \mathrm{M})$ to the aCSF. The patch electrode-filling solution consisted of $120 \mathrm{~mm}$ K-gluconate, $10 \mathrm{~mm} \mathrm{KCl}, 10 \mathrm{~mm}$ HEPES, 0.2 mm EGTA, 2 mм Mg-ATP, 0.3 mм Na-GTP, pH 7.3 (osmolarity 300-305 mOsm). To block the rise of postsynaptic $\mathrm{Ca}^{2+}$ levels in Type III neurons, in some experiments, $\mathrm{Ca}^{2+}$ was buffered with $20 \mathrm{~mm}$ of the BAPTA in the intracellular solution, whereas the K-gluconate concentration was reduced to $100 \mathrm{~mm}$. IL-18 was added to the aCSF at a final concentration of 10,50 , and 100 $\mathrm{ng} / \mathrm{ml}$ for $15 \mathrm{~min}$ and then washout for $15 \mathrm{~min}$. Type III neurons were characterized by the following: (1) A fast reduction in the voltage response (inward rectification) evoked by hyperpolarizing current injection (350 ms in duration) of increasing amplitude (Szücs et al., 2010). (2) The presence of a slow depolarization, ramp-like, of the membrane potential in response to depolarizing current pulses. This behavior is due to the slowly inactivating potassium current $\left(\mathrm{I}_{\mathrm{D}}\right)$ (Storm, 1988). (3) Delayed action potential when depolarizing current pulses were applied. Neurons with those electrophysiological characteristics were recorded in the jcBST adjacent to the internal capsula (see also Rodríguez-Sierra et al., 2013). Type I neurons are characterized by the presence of voltage sag during hyperpolarization suggestive of the expression of Ih. Type II neurons show a voltage sag stronger than in Type I neurons and generate postinhibitory spikes at the end of hyperpolarizing current steps. The AMPA-mediated postsynaptic currents (AMPA-EPSCs) were recorded, from previously physiologically identified jcBST neurons, in voltage-clamp mode at the holding voltage of $-70 \mathrm{mV}$.

To evoke synaptic currents, paired stimuli (50 ms interpulse interval) were delivered at $0.05 \mathrm{~Hz}$ through a bipolar stimulating electrode placed in the stria terminalis. Constant-current pulses of $0.08 \mathrm{~ms}$ duration were used, and the intensity was set to evoke an EPSC of $\sim 70 \mathrm{pA}$ in amplitude for every cell studied. The evoked AMPA (eAMPA)-EPSCs recorded 10 min before IL-18 application were used to calculate baseline values for peak EPSC amplitude. The paired pulse ratio (PPR) was then calculated as the peak amplitude of the second eAMPA-EPSC (eAMPA-EPSC2) divided by the first, eAMPA-EPSC1 (PPR = eAMPA-EPSC2/eAMPAEPSC1). Alterations in the PPR are thought to represent changes in release probability in the presynaptic terminal (Manabe et al., 1993). As an alternative parameter, to determine the synaptic mode of IL-18 action, we measured the coefficient of variation (CV) of the eAMPA-EPSCs as the ratio of the SD $(\delta)$ to the mean $(\mu)$ of the peak eAMPA-EPSC amplitude. A change of CV is associated with either a change of release probability (Pr) or the number of release sites ( $n$ ) (Choi and Lovinger, 1997). Input-output $(\mathrm{I} / \mathrm{O})$ curves were calculated to estimate the synaptic efficacy of AMPAR responses. After electrophysiological characterization of evoked synaptic responses, neurons were clamped at $-70 \mathrm{mV}$, and the spontaneous miniature AMPA (mAMPA)-EPSCs were recorded in slices perfused with TTX $(0.5 \mu \mathrm{M})$ to block action potentials. The threshold to detect the mAMPA-EPSCs was established at $6 \mathrm{pA}$ of amplitude. To generate the cumulative probability curve, we recorded 2000-3000 events. The cumulative probability curve for interevent intervals and mini-amplitude before and after IL- 18 were generated by recording from the same cell.

Statistical analysis. Data are presented as mean \pm SEM. Statistical differences were determined on raw data by repeated-measures ANOVA and the Kolmogorov-Smirnov test at a significance level of 0.05 . c-fos data were analyzed by $t$ test.

\section{Results}

Expression of IL-18R $\alpha$ and $\beta$ in the anterior BST

The detailed distribution of IL-18R $\alpha$ and IL-18R $\beta$ mRNAs in the anterior BST was determined via ISH in the brain of C57BL/6J mice $(n=5)$. Representative images are shown in Figure 1. IL$18 \mathrm{R} \alpha$ Type I was expressed in the anterolateral BST, with the 

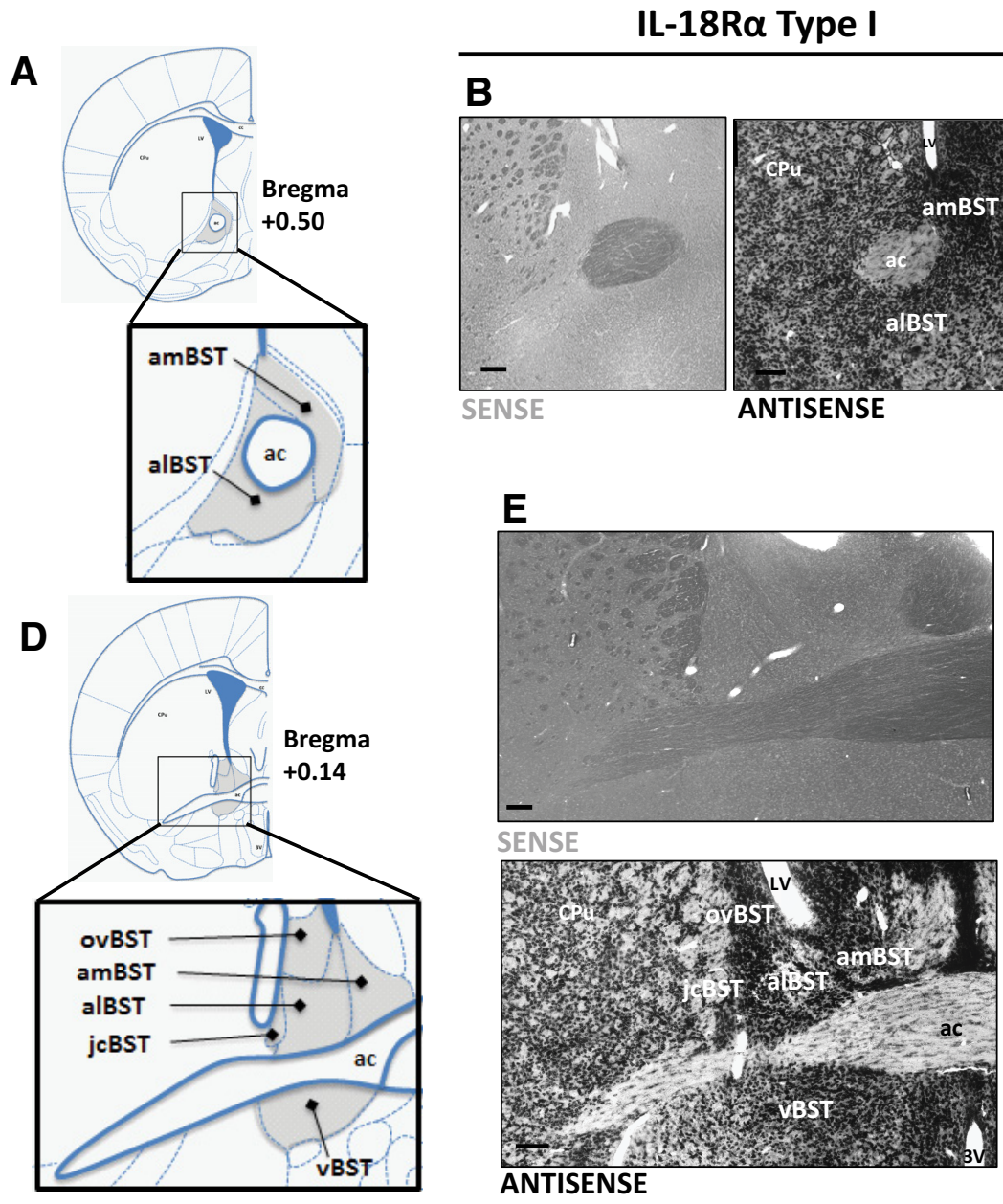

ANTISENSE
IL-18R $\beta$
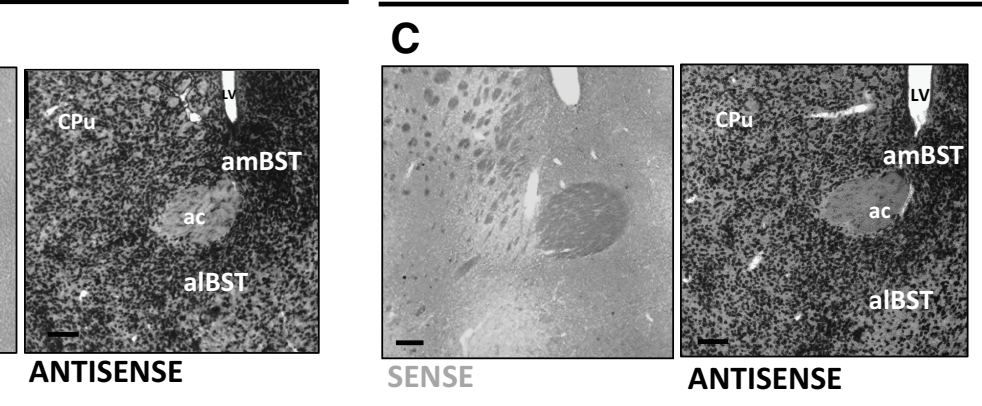

$\mathbf{F}$
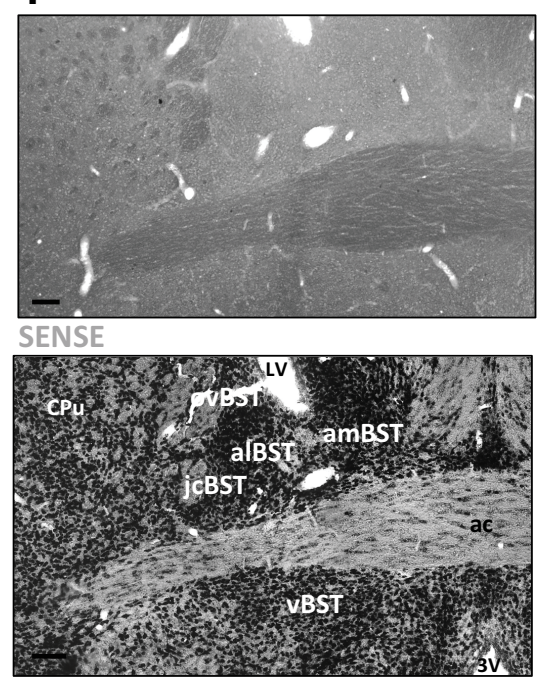

ANTISENSE

Figure 1. Distribution of IL-18R $\alpha$ and $\beta$ in the BST. A, D, Coronal section schematics adapted from Franklin and Paxinos (1997) and Allen Mouse Brain Atlas (http://mouse.brain-map.org) showing the location of BST and its nuclei. $\boldsymbol{B}, \boldsymbol{E}$, Distribution of IL-18R $\alpha$ and mRNAs in the BST of C57BL/6J mice. $\boldsymbol{C}$, $\boldsymbol{F}$, Distribution of IL-18R $\beta$ mRNAs in the BST of C57BL/6J mice. Expression of the mRNAs of interest was demonstrated by using in situ hybridization with a DIG-labeled antisense cRNA-specific probe (ANTISENSE) and using a sense cRNA probe (SENSE) as a negative control. Section hybridized with the sense riboprobes showing the absence of hybridization signal (SENSE). amBST, Anterior division BST, medial; vBST, anterior division BST, ventral; cc, corpum callosum; (Pu, caudate-putamen; ac, anterior commissure; LV, lateral ventricle; 3v, third ventricle. Scale bar, $100 \mu \mathrm{m}$.

densest staining seen in the oval and juxtacapsular nucleus. Hybridization signal was also observed for IL- $18 \mathrm{R} \alpha$ in the anteromedial BST (Fig. $1 A, B, E$ ). The expression of IL-18R $\beta$ mRNA did not appear to differ strongly between lateral versus medial divisions (Fig. $1 C, F$ ). In all cases, the specificity of the hybridization signals was confirmed by comparing sections hybridized with antisense probes with those hybridized with respective sense probes; no hybridization signal was detectable in sections hybridized in parallel with sense probes (Fig. $1 B, C, E, F$ ). Divisions of the BST were identified by comparison with the Franklin and Paxinos Mouse Brain Atlas in stereotaxic coordinates (Franklin and Paxinos, 1997). The anatomic nomenclature used in this study was based on the Allen Mouse Brain Atlas (http://mouse.brain-map.org).

\section{Administration of recombinant IL-18 in the adBST reduced food intake and c-fos activation}

The effects of IL-18 on food intake and c-fos activation were measured following bilateral injection of recombinant mouse IL-18 (rmIL-18) or aCSF (used as vehicle) into the adBST of mice refed after $17 \mathrm{~h}$ of food deprivation $(n=6$ animals per group). rmIL-18 (30 ng/0.2 $\mu \mathrm{l})$ markedly reduced food intake and c-fos activation (Fig. 2); 75\% of cannulations were on target, and off-target cannulation did not have any significant effect on food intake compared with target vehicle (data not shown).

Repeated-measures ANOVA showed that IL-18 microinjection reduced food intake starting at $3 \mathrm{~h}$ (Zeitberger time $7 \mathrm{~h}$ ) after injection (treatment $\times$ time: $F_{(1,22)}=63.84, p<0.0001$; Fig. $2 A$ ). Cumulative food intake indicated a reduction at $3 \mathrm{~h}(55.6 \pm$ $14.7 \%$, normalized to controls $)$ and $6 \mathrm{~h}(52.8 \pm 14.7 \%$, normalized to controls) after rmIL-18 injection. Significant hypophagia was also observed when food intake was normalized for body weight (treatment $\times$ time: $F_{(1,39)}=9.92, p<0.01$; Fig. $2 B$ ).

Administration of rmIL-18 in the adBST did not affect core body temperature, locomotor activity, the respiratory exchange ratio $\left(\mathrm{RER}=\mathrm{VCO}_{2} / \mathrm{VO}_{2}\right)$, or heat production (see Fig. 3). These data indicate that injecting rmIL-18 in the adBST did not alter the index of carbohydrates versus lipid usage and did not cause fever, ruling out the possibility that the effects of rmIL-18 on feeding were due to the possible presence of endotoxin contaminant.

c-fos immunostaining was used to determine the effects of rmIL-18 on adBST activation. rmIL-18 reduced the activation of $\mathrm{c}$-fos in the BST. The number of neurons per slice per area \pm SEM for vehicle versus IL-18 (rounded up to no decimals) was as follows: $51 \pm 6$ versus $12 \pm 1$ in the anterior BST $(N=4$ animals per 
A

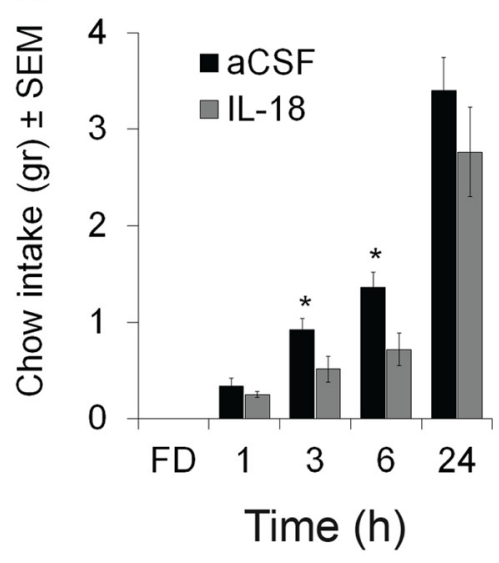

B

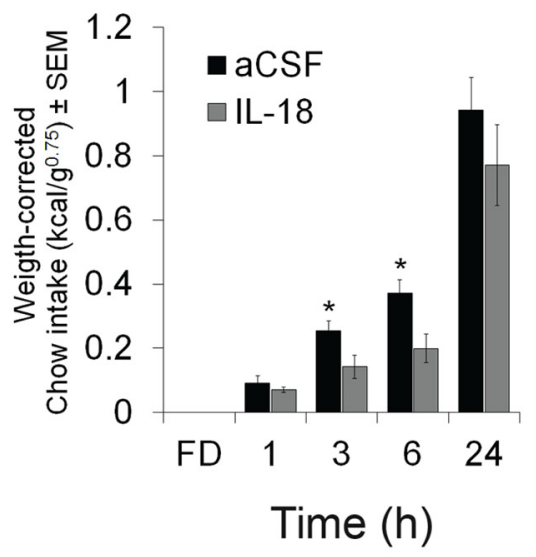

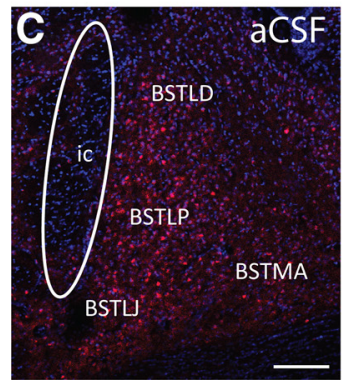
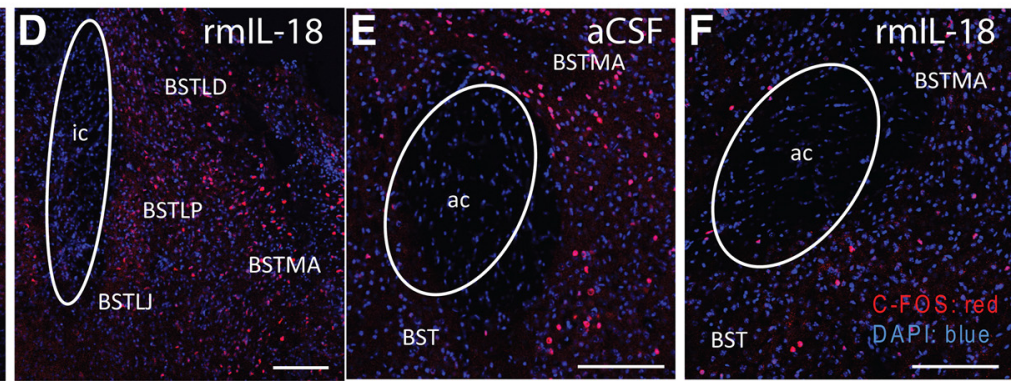

Figure 2. Infusion of IL-18 in the BST reduced feeding and c-fos activation. The effects of IL-18 on food intake and on c-fos activation were performed on brains of animals that were food-deprived overnight for $17 \mathrm{~h}$ before receiving bilateral microinjection of rmlL-18 (0.34 nmol/mouse) or vehicle (aCSF) into the BST through a previously implanted the implanted cannulas. $A$, Histogram showing cumulative grams of food intake in $/ 118 \mathrm{ra}^{+/+}$mice treated with rmIL-18 in the BST or with aCSF measured at different time-points after IL-18 administration. $\boldsymbol{B}$, The same analysis was performed normalizing grams of food intake to body weight. Significant hypophagia was observed $3 \mathrm{~h}\left({ }^{*} p<0.0001\right)$ and $6 \mathrm{~h}(p<0.05)$ after injection of IL-18 in the BST. FD, Food deprivation. Data are mean \pm SEM; $n=6$ animals per group. $\mathbf{C}-\boldsymbol{F}$, Representative picture of $\mathrm{c}-$ fos immunofluorescent staining in the BST of $/ 118 \mathrm{ra}{ }^{+/+}$mice at $3 \mathrm{~h}$ after injection of rmIL-18.

group; $t_{(6)}=6.1577, p<0.01, t$ test $)$ and $46 \pm 15$ versus $21 \pm 2$ in the jcBST $\left(N=4\right.$ animals per group; $t_{(6)}=3.2764, p<0.01, t$ test). Representative pictures are shown in Figure $2 C-F$. These data indicate that IL-18 reduces the activation of adBST neurons, including those in the jcBST projecting to the lateral hypothalamus.

\section{IL-18 affects intrinsic membrane properties of Type III but not of Type I/II alBST neurons via IL-18R}

In $I l 18 \mathrm{ra}^{+/+}$mice, the intrinsic membrane properties of Type III jcBST neurons, such as resting membrane potential, input resistance, rheobase, input-output (I/O) function, and voltage threshold, were determined, in current-clamp recordings, by analyzing the voltage-evoked responses to intracellular injections of a series of hyperpolarizing and depolarizing current pulses. Current pulses of $350 \mathrm{~ms}$ starting from $-200 \mathrm{pA}$ were increased in steps of $5 \mathrm{pA}$ until firing was elicited. In every type of cell recorded, these parameters were measured before and during a 15 min bath application of rmIL-18 and then again during washout to verify the possible effects of rmIL-18 on postsynaptic membrane conductances. rmIL-18 was used at $50 \mathrm{ng} / \mathrm{ml}$, a concentration determined in pilot dose-response experiments that were performed with 10,50 , or $100 \mathrm{ng} / \mathrm{ml}$ ( $n=4$ cells per concentration). No effects were observed at 10 $\mathrm{ng} / \mathrm{ml}$, and no difference in the response was observed between 50 and $100 \mathrm{ng} / \mathrm{ml}$ (data not shown).

As shown in Table 1, in Type III jcBST neurons, rmIL-18 significantly depolarized the resting membrane potential from $-73.66 \pm 2.0 \mathrm{mV}$ to $-53.41 \pm 3.55 \mathrm{mV}$ after $15 \mathrm{~min}$ bath application $\left(F_{(1,18)}=29.87, p=0.000398\right)$. This strong depolarizing effect of rmIL-18 was not associated with appearance of spontaneous firing. The depolarization was associated with a significant increase in input resistance from $415.25 \pm 22.73 \mathrm{M} \Omega$ to $686.5 \pm$ $34.8 \mathrm{M} \Omega\left(F_{(1,14)}=54.71, p=0.00015\right)$, measured in response to $-200 \mathrm{pA}$ hyperpolarizing current pulse. The increase in the input resistance of Type III neurons treated with rmIL-18 was associated with a reduction of the inward rectification and of the rheobase current from $96.67 \pm 6.55 \mathrm{pA}$ before application to $39.62 \pm 4.84 \mathrm{pA} 15 \mathrm{~min}$ after rmIL-18 (50 ng/ml) application $\left(F_{(1,6)}=52.85, p<0.0001\right)$. However, this change in the rheobase was not associated with a significant change in the voltage threshold of Type III neurons $(-34.86 \pm 0.65 \mathrm{mV}$ before and $-34.58 \pm$ $0.76 \mathrm{mV}$ after application of rmIL-18; $\left.F_{(1,20)}=0.11, p=0.747\right)$. The slope of the I/O function (no. of spikes/nA), which is a measure of neuronal excitability, was not significantly altered after 15 min of rmIL-18 application $(81.17 \pm 6.7$ before and $55.49 \pm 7.37$, at $15 \mathrm{~min}$ rmIL-18 application; $\left.F_{(1,16)}=6.6506 p=0.2239\right)$. IL-18 can induce these membrane effects reducing the $\mathrm{I}_{\mathrm{KIR}}$, which strongly controls the resting membrane potential, input resistance in the hyperpolarized region, and the rheobase of the Type III BST neurons, together with other ionic currents.

To determine the involvement of IL-18 receptors in IL-18induced changes in Type III neuron intrinsic membrane properties, similar electrophysiological studies were conducted in brain slices prepared from Il18 $\mathrm{ra}^{-/-}$mice, which lack functional IL-18 receptors. rmIL-18 (50 ng/ml) did not induce significant changes in the intrinsic membrane properties of Type III jcBST neurons from Il18ra ${ }^{-/-}$mice (Table 1). The results demonstrate that the changes induced in Type III jcBST neurons in $\mathrm{Il1}_{\mathrm{rra}} \mathrm{rl}^{+/}$mice by IL-18 on the resting membrane potential, the input resistance, 


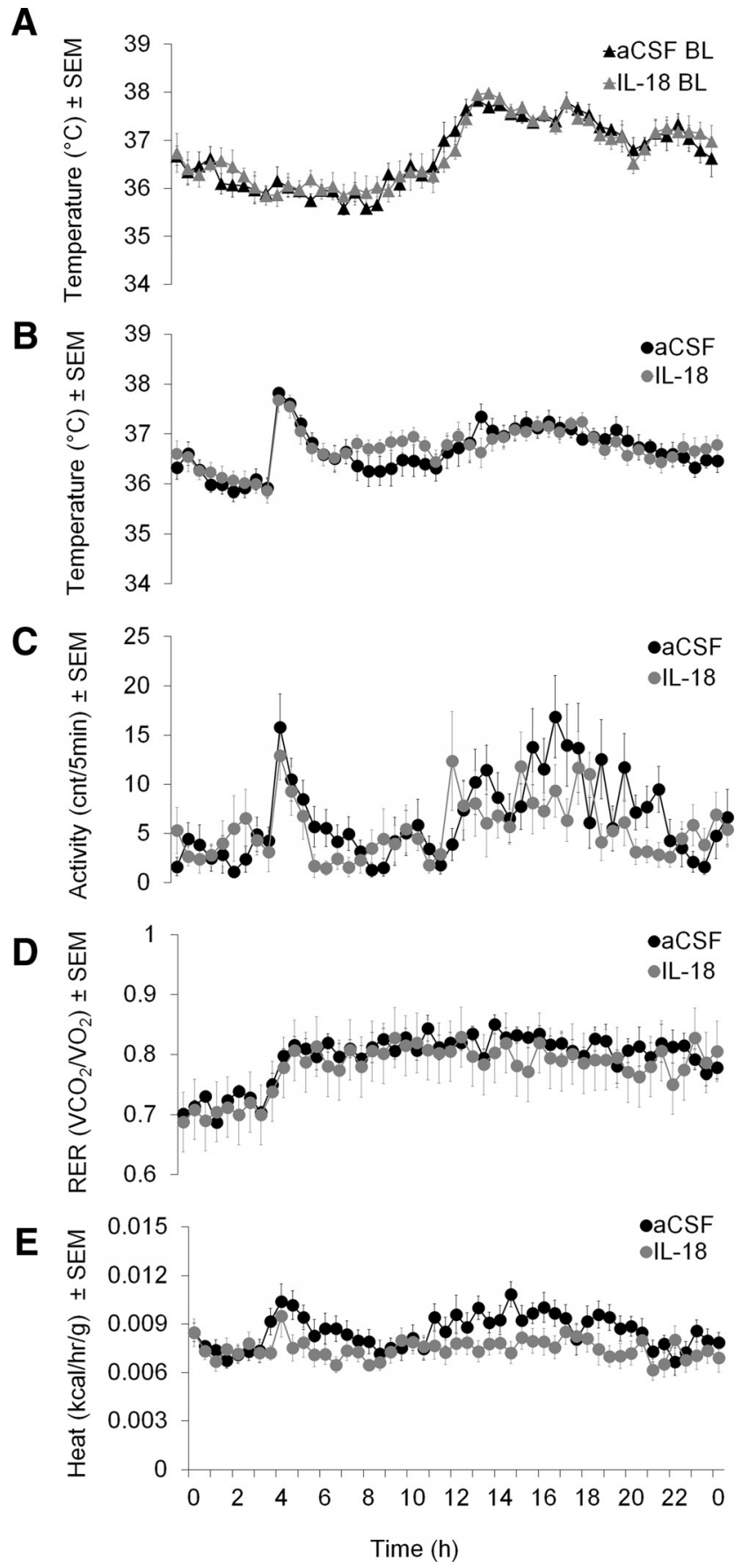

Figure 3. Effects of infusion of IL-18 in the BST on metabolic parameters. $A$, Basal circadian CBT profile of $/ 118 \mathrm{ra}^{+/+}$groups of mice used to measure the possible pyretic effects of IL-18. $\boldsymbol{B}$, CBT profile of $/ 118 \mathrm{ra}^{+/+}$mice following BST injection of rmIL-18 or aCSF used as vehicle. $C$, Locomotor activity of $/ 118 \mathrm{ra}{ }^{+/+}$mice following BST injection of rmIL-18 or aCSF used as vehicle. D, Respiratory exchange ration of $/ 118 \mathrm{ra}^{+/+}$mice following BST injection of rmIL-18 or aCSF used as vehicle. $\boldsymbol{E}$, Indirect calorimetry of $/ 118 \mathrm{ra}^{+/+}$mice following BST injection of rmIL-18 or aCSF used as vehicle. Data are mean $\pm \mathrm{SEM} ; n=6$ animals per group.

and the rheobase are mediated by the functional IL-18R complex. In light of evidence that stress can differentially modulate the properties of Type I, II, and III neurons in the jcBST, we sought to determine whether the effects of IL-18 on Type III neuron intrinsic properties were also evident in Type I and Type II neurons. As shown in Table 1, bath application of rmIL-18 $(50 \mathrm{ng} / \mathrm{ml})$ did not change the intrinsic membrane properties of Type I and II neurons, contrary to what was seen in Type III neurons. The results support the hypothesis that Type III and Type I/II BST neurons may differentially subserve jcBST functions and implicate Type III neurons in the control of food intake.

\section{IL-18 decreases the amplitude of evoked AMPA-EPSCs at glutamatergic inputs to Type III jcBST neurons by modulating presynaptic glutamate release}

We next investigated the effects of rmIl-18 $(50 \mathrm{ng} / \mathrm{ml})$ on glutamatergic synaptic transmission to Type III BST neurons (Fig. 4). Type III jcBST neurons receive excitatory input from many cortical and limbic areas, including the dysgranular insular cortex, the prelimbic and infralimbic divisions of the mPFC, the amygdalo-hippocampal transition area, the posterior BLA, the transitional postpyriform cortex, and the amygdalopiriform transition area (McDonald et al., 1999; Dong et al., 2001; LarrivaSahd, 2004). Pharmacologically isolated AMPA-EPSCs (see Materials and Methods) were evoked in Type III BST neurons by electrical stimulation of the stria terminalis (Francesconi et al., 2009) (Fig. 4A-B). eAMPA-EPSCs were recorded every $20 \mathrm{~s}$ for $10 \mathrm{~min}$ in aCSF, during $15 \mathrm{~min}$ of rmIL-18 $(50 \mathrm{ng} / \mathrm{ml})$ bath application, and during $15 \mathrm{~min}$ of washout. rmIL-18 gradually reduced the peak amplitude of the eAMPA-EPSCs from $70.27 \pm$ $0.19 \mathrm{pA}$ to $28.7 \pm 0.28 \mathrm{pA}$ (40.6 $\pm 0.26 \%$ of baseline value) at $10-15$ min of application $\left(F_{(2,42)}=3065.7, p<0.0001\right.$; Fig. $4 C-$ $E)$. A partial recovery of the peak amplitude of eAMPA-EPSCs to $34.5 \pm 0.52 \mathrm{pA}$ was observed during the $15 \mathrm{~min}$ of washout (Fig. $4 D)$. A comparable reduction of eAMPA-EPSC peak amplitude was observed at $100 \mathrm{ng} / \mathrm{ml} \mathrm{rmIL-18}(n=4)$, whereas no effects were seen at $10 \mathrm{ng} / \mathrm{ml}(n=4)$ (data not shown). In control experiments, we recorded eAMPA-EPSCs for a period of $30 \mathrm{~min}$ in regular aCSF to assess possible rundown of the eAMPA-EPSCs with time. The peak amplitude of eAMPA-EPSCs remained stable during the recording period.

\section{Synaptic site of action}

The IL-18-induced reduction of eAMPA-EPSC amplitude could be due to either presynaptic or postsynaptic mechanisms, or both. To clarify the synaptic mode of IL-18 action, we first performed a series of experiments using a paired-pulse paradigm in which two pulses are applied with a $50 \mathrm{~ms}$ interstimulus interval. A typical response to paired pulse stimulation is shown in Figure $4 C$. We measured both the PPR and the CV of the eAMPA-EPSCs before and during rmIL-18 (50 ng/ml) bath application (for PPR and CV measures, see Materials and Methods). PPR changes are considered to indicate a change in the probability of synaptic vesicle release, as occurs with alterations in presynaptic calcium influx (Manabe et al., 1993). The CV is a sensitive parameter of presynaptic function because it varies per variables, such as number of release $(n)$ and probability of release $(p)$ (Manabe et al., 1993). The reduction of the eAMPA-EPSC peak amplitude induced by rmIL-18 $(50 \mathrm{ng} / \mathrm{ml})$ corresponded temporally with an increase in the PPR (Fig. 4D,E). Statistical analysis showed a significant increase of both PPR from $0.97 \pm 0.009$ to $1.86 \pm 0.09$ $\left(190 \pm 9.38 \% ; F_{(2,42)}=62.62, p<0.001\right)$ and $\mathrm{CV}$ from $0.10 \pm$ 0.006 to $0.32 \pm 0.037\left(318 \pm 46.2 \% ; F_{(2,15)}=21.41, p=\right.$ $0.000243)$ at $10-15 \mathrm{~min}$ of application of rmIL-18 $(50 \mathrm{ng} / \mathrm{ml})$ (Fig. $4 D, E$ ). The joint increase of PPR and $C V$ suggests a decrease in presynaptic glutamate release probability following IL-18 application. To further test the hypothesis that IL-18 alters presynaptic activity, we also recorded action potential independent spontaneous mAMPA-EPSCs from Type III neurons clamped at $-70 \mathrm{mV}$ in BST slices perfused with TTX (see Materials and Methods) to inhibit action potential evoked release. As shown in 
Table 1. Intrinsic membrane properties of Type III, II, and I BST neurons, before, and during IL-18 $(50 \mathrm{ng} / \mathrm{ml})$ bath application in II18ra ${ }^{+/+}$mice and II18ra $^{-/-}$mice ${ }^{a}$

\begin{tabular}{|c|c|c|c|c|c|}
\hline & Resting membrane potential (mV) & Input resistance (m $\Omega$ ) & Rheobase (pA) & Input- output (no. of spikes/nA) & Threshold (mV) \\
\hline \multicolumn{6}{|c|}{ Neurons from $/ / 18 \mathrm{ra}^{+/+}$mice } \\
\hline \multicolumn{6}{|c|}{ Type III $(n=7)$} \\
\hline$+\mathrm{aCSF}$ & $-73.66 \pm 2.0$ & $415.25 \pm 22.73$ & $96.67 \pm 6.55$ & $81.17 \pm 9.8$ & $-34.86 \pm 0.65$ \\
\hline+ rmlL-18 & $-53.41 \pm 3.55^{*}$ & $686.5 \pm 34.80^{*}$ & $39.62 \pm 4.84^{*}$ & $55.4 \pm 7.37$ & $-34.58 \pm 0.76$ \\
\hline \multicolumn{6}{|l|}{ Type I $(n=6)$} \\
\hline$+\mathrm{aCSF}$ & $-65.77 \pm 1.74$ & $245.98 \pm 30.09$ & $93.83 \pm 14.15$ & $28.50 .1 \pm 2.43$ & $-35.29 \pm 1.03$ \\
\hline+ rmlL-18 & $-63.41 \pm 1.61$ & $252.45 \pm 56.53$ & $91.16 \pm 22.61$ & $37.53 \pm 4.23$ & $-36.14 \pm 1.2$ \\
\hline \multicolumn{6}{|l|}{ Type II $(n=6)$} \\
\hline$+\mathrm{aCSF}$ & $-56.75 \pm 0.36$ & $248.33 \pm 8.68$ & $20.83 \pm 1.24$ & $67.31 \pm 4.15$ & $-35.78 \pm 1.0$ \\
\hline$+\mathrm{rmlL}-18$ & $-58.59 \pm 1.164$ & $274.23 \pm 9.55$ & $30.16 \pm 4.37$ & $45.43 \pm 7.48$ & $-35.95 \pm 1.08$ \\
\hline \multicolumn{6}{|c|}{ Neurons from $/ / 18 \mathrm{ra}^{-1-}$ mice } \\
\hline \multicolumn{6}{|c|}{ Type III $(n=7)$} \\
\hline$+\mathrm{aCSF}$ & $-70.48 \pm 2.71$ & $394.36 \pm 67.63$ & $61.15 \pm 17.86$ & $67.8 \pm 7.3$ & $-34.79 \pm 2.35$ \\
\hline+ rmlL-18 & $-70.3 \pm 4.04$ & $327 \pm 73.65$ & $51.39 \pm 13.19$ & $63.6 \pm 12$ & $-34.74 \pm 0.96$ \\
\hline
\end{tabular}

${ }^{a}$ Values are mean \pm SEM. IL-18 significantly affects the resting membrane potential, the input resistance, and the rheobase only in Type III neurons in $/ / 18 \mathrm{ra}^{+/+}$mice. The input- output slope was unchanged, suggesting that IL-18 has no effect on the intrinsic excitability of Type III neurons. IL-18 had no effects in slices prepared from I/18ra ${ }^{-1-}$ mice.

${ }^{*} p<0.01$.

A

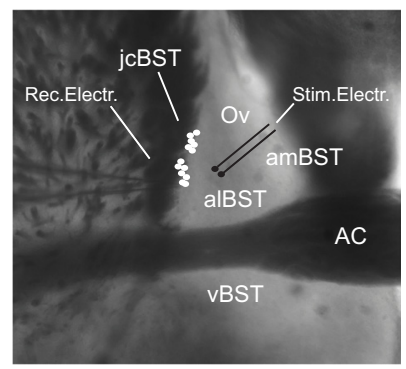

D

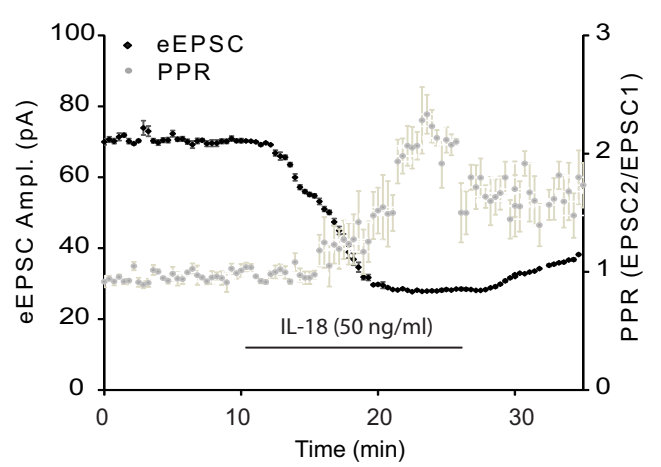

B

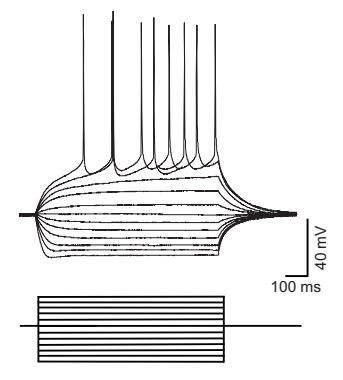

E
C

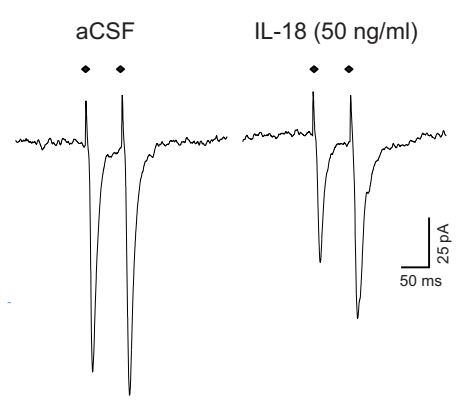

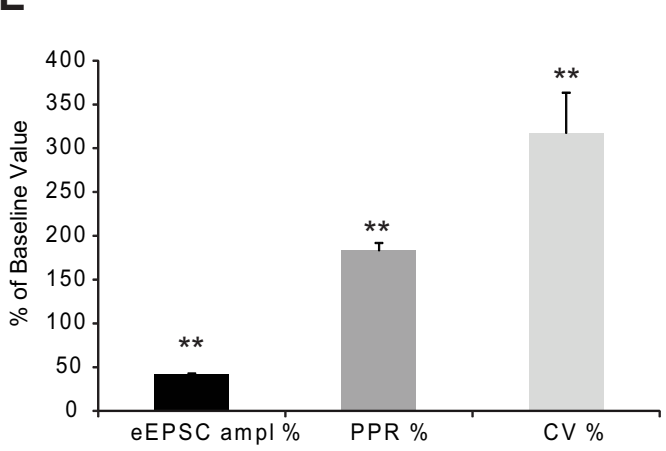

Figure 4. rmIL-18 reduces the amplitude of eAMPA-EPSC in $/ 18 \mathrm{ra}^{+/+}$mice. A, Photomicrograph of a brain slice at the level of the BST demonstrating electrode placements for stimulation (Stim. Electr.) and electrophysiological recordings (Rec. Electr.). Dots represent the location of the Type III recorded neurons. amBST, Anterior division BST, medial; Ov, oval nucleus; vBST, ventral BST; AC, anterior commissure. $\boldsymbol{B}$, Voltage traces in response to hyperpolarizing and depolarizing current pulses injected in a typical Type III neuron of jcBST. The Type III neurons are characterized by a strong inward rectification current (Ikir) in the hyperpolarized region. Moreover, Type III neurons respond to depolarized pulse near threshold, with a delayed action potential at the end of a slow depolarization. This delayed spike is due to the activation of $\mathrm{I}_{D}$ current. $C$, eAMPA-EPSCs in response to paired electrical shocks applied to the stria terminalis with an interstimulus interval of $50 \mathrm{~ms}$, before (aCSF) and at 12 min of IL-18 application. The first eAMPA-EPSC amplitude is reduced during rmIL-18 application. $\boldsymbol{D}$, Temporal profile of the effects of rmIL-18 on eAMPA-EPSC amplitude (black diamonds) and on PPR (gray diamonds). E, Percentage values of the mean amplitude of eAMPA-EPSCs (black column), of the PPR (dark gray column), and of the CV (light gray column) measured in 7 BST Type III neurons after $12 \mathrm{~min}$ of rmlL-18 $(50 \mathrm{ng} / \mathrm{ml})$ bath application. Data are mean \pm SEM, expressed as percentage of baseline values measured for $10 \mathrm{~min}$ before $\mathrm{rmlL}-18$. ${ }^{* *} p<0.001$.

Figure $5 A, C$, application of rmIL-18 (50 ng/ml) caused a significant decrease in the frequency of mAMPA-EPSCs from $5.63 \pm$ $0.42 \mathrm{~Hz}$ to $2.86 \pm 0.18 \mathrm{~Hz}\left(F_{(2,18)}=40.09, p<0.0001,12 \mathrm{~min}\right.$ after IL-18), with no significant associated change in the amplitude $\left(15.27 \pm 1.53 \mathrm{pA}\right.$ to $12.07 \pm 1.46 \mathrm{pA} ; F_{(2,15)}=1.73, p=$ 0.2263, 15 min after rmIL-18). Moreover, rmIL-18 induced a rightward shift in the cumulative frequency distribution of spon- taneous release events ( $p<0.05$, Kolmogorov-Smirnov statistic) without a significant change in cumulative amplitude distribution (Fig. $5 E$ ). These results support an effect of IL-18 on the presynaptic activity of glutamatergic terminals on Type III jcBST neurons. However, because rmIL-18 (50 ng/ml) significantly depolarized postsynaptic Type III neurons, a retrograde signal can be released as consequence of intracellular $\mathrm{Ca}^{2+}$ increase. To 
A

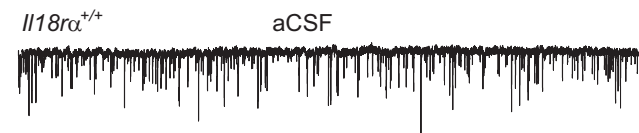

$1 / 18 \mathrm{ra}^{+/+}$

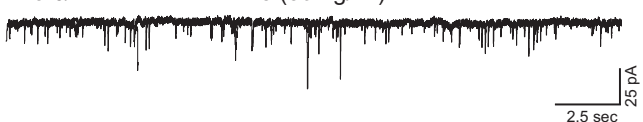

C
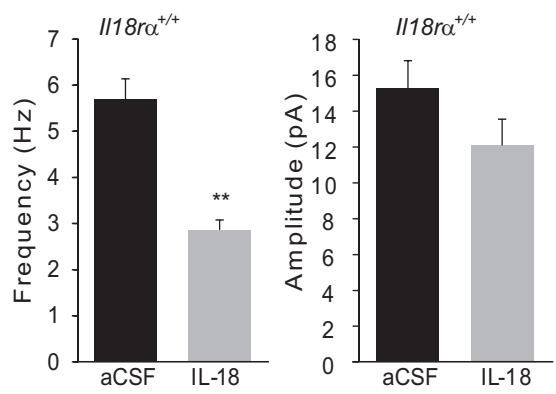

E
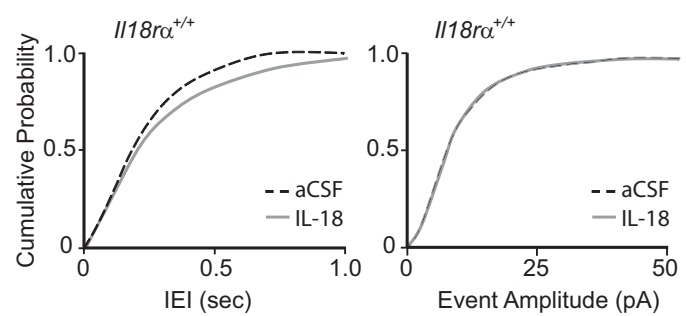

B

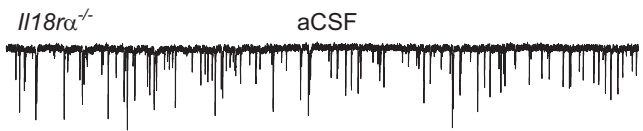

$1 / 18 \mathrm{r \alpha}^{-/-} \quad \mathrm{rmlL}-18(50 \mathrm{ng} / \mathrm{ml})$

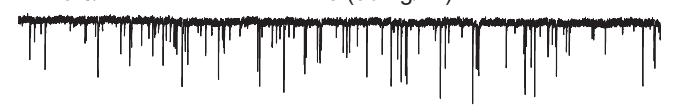

D
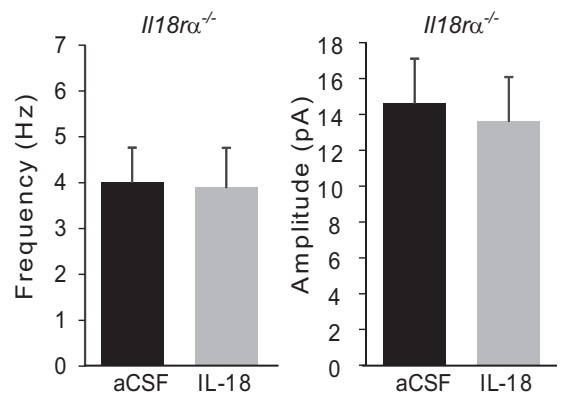

$\mathbf{F}$

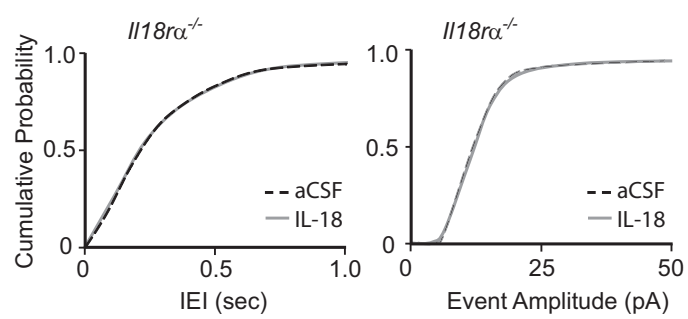

Figure 5. rmIL-18 reduces the frequency of mAMPA-EPSCs in $/ 188 \mathrm{ra}^{+/+}$mice and not in $/ / 18 \mathrm{ra}^{-/-}$mice. $A, B$, Representative traces of the mAMPA-EPSCS recorded from a jcBST Type III neuron before and $12 \mathrm{~min}$ after rmlL-18 (50 ng/ml) in //18ra ${ }^{+/+}$and $/ 118 \mathrm{ra}^{-/-}$mice, respectively. C, D, Frequency and amplitude mean values of mAMPA-EPSCS in Type III BST neurons $(n=7)$ before (black columns) and $12 \mathrm{~min}$ after (gray columns) rmlL- $18(50 \mathrm{ng} / \mathrm{ml})$ bath application in $/ 118 \mathrm{ra}^{+/+}$and $/ / 18 \mathrm{ra}{ }^{-/-}$mice, respectively. ${ }^{* *} p<0.0001$. E, $F$, Cumulative probability curves of the

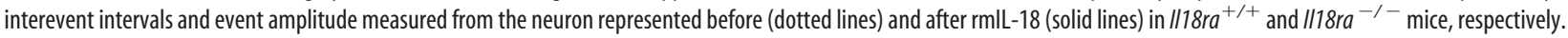

exclude this possibility, we conducted experiments in 6 Type III neurons where the intracellular recording solution was supplemented with $20 \mathrm{~mm}$ BAPTA. Under this condition, rmIL-18 (50 $\mathrm{ng} / \mathrm{ml}$ ) still reduced the frequency of mAMPA-EPSCs from $5.69 \pm 0.45 \mathrm{~Hz}$ to $2.89 \pm 0.18 \mathrm{~Hz}, 15 \mathrm{~min}$ after rmIL-18 $\left(F_{(2,15)}=\right.$ $41.08 p<0.0001)$, leaving the mean amplitude unchanged $\left(13.73 \pm 0.57 \mathrm{pA}\right.$ to $12.98 \pm 0.82 \mathrm{pA} 15 \mathrm{~min}$ after rmIL-18; $F_{(2,15)}$ $=0.6 p=0.567)$. These results strongly indicate a direct presynaptic effect of IL-18. The modulation of mAMPA-EPSCs by IL-18 was tested also in $I l 18 \mathrm{ra}^{-/-}$mice. rmIL-18 $(50 \mathrm{ng} / \mathrm{ml})$ did not change either the frequency (from $4.01 \pm 0.75$ to $3.89 \pm 0.87$; $F_{(2,15)}=0.19 p=0.829$ ) or the amplitude (from $14.15 \pm 2.69$ to $\left.13.72 \pm 2.48 ; F_{(2,15)}=0.27 p=0.768\right)$ of spontaneous synaptic events (Fig. $5 B, D, F$ ). Thus, IL-18 modulated the excitatory synaptic input onto Type III BST neurons through the IL-18R complex.

\section{Type III cell specificity of IL-18 actions}

To investigate whether the effects of IL-18 on Type III neurons of jcBST were cell specific, we performed patch-clamp recording from electrophysiologically identified Type I and Type II neurons. Interestingly, Type I and Type II neurons received a significantly lower frequency of mAMPA-EPSCs. In Type I neurons, the frequency of mAMPA-EPSCs was $1.61 \pm 0.42 \mathrm{~Hz}$ with mean amplitude of $11.44 \pm 1.39 \mathrm{pA}$. The mAMPA-EPSCs frequency in Type II neurons was $<1 \mathrm{~Hz}$, and too low to acquire sufficient events for a formal statistical analysis. Therefore, we analyzed the effects of IL-18 on only Type I neurons. Bath application of rmIL-18 $(50 \mathrm{ng} / \mathrm{ml})$ did not significantly change the frequency or amplitude of mAMPA-EPSCs in Type I alBST neurons. The mean frequency of mAMPA-EPSCs in Type I neurons was $1.61 \pm$ $0.42 \mathrm{~Hz}$ before and $1.88 \pm 0.45 \mathrm{~Hz}, 15 \mathrm{~min}$ after rmIL- $18\left(F_{(1,8)}=\right.$ $3.24 p=0.146)$, whereas the mean amplitude of mAMPA-EPSCs was $11.44 \pm 1.39 \mathrm{pA}$ before and $11.7 \pm 1.19 \mathrm{pA}, 15 \mathrm{~min}$ after $\operatorname{rmIL}-18\left(F_{(1,8)}=0.63 p=0.471\right)$. Thus, IL-18 selectively modified presynaptic release at glutamatergic terminals that made synaptic contact on Type III jcBST neurons.

\section{Discussion}

The present work identified the adBST as a site of the anorexigenic action of IL-18 and showed that this is mediated by the modulation of the excitatory synaptic input of Type III neurons in the jcBST. IL-18 altered presynaptic glutamate release via its functional IL-18 receptor. A schematic representation of these findings is presented in Figure 6.

\section{IL-18 and food intake}

Behavioral, pharmacological, and molecular studies have recently implicated a central role for IL-18 to control food intake. Mice lacking IL-18 or a functional IL-18 receptor eat more and gain more weight than their wild-type littermates. Conversely, intracerebroventricular administration of recombinant IL-18 reduced food intake (Netea et al., 2006; Zorrilla et al., 2007; Zorrilla and Conti, 2014; Hale et al., 2015). Recently, it was also shown that activation of neurons in the adBST promoted feeding by inhibiting glutamatergic $\mathrm{LH}$ neurons that regulate nutrient homeostasis (Jennings et al., 2013). Specifically, the effects seem to involve GABAergic neurons located in the jcBST that project to 
the LH (Dong et al., 2000). A combined Golgi and electron microscopic study of the jcBST revealed two basic cell types: interneurons and projection neurons; $80 \%$ of such neurons were described as bipolar projection neurons, suggesting that GABAergic neurons may function as both intrinsic interneurons and projection neurons (Larriva-Sahd, 2004). The jcBST neurons receive excitatory inputs from many cortical and limbic areas, including the dysgranular insular cortex, a cortical area involved in gustatory perception (Small, 2010), in the processing of visual food-cues (Frank, 1952), tasted or smelled food stimuli (de Araujo et al., 2003), and also in food craving (Pelchat et al., 2004). We found that both heterodimeric subunits of a functional IL-18R (IL-18R $\alpha$ and IL-18 $\beta$ ) are expressed in the jcBST, and we hypothesized that IL-18 may influence feeding by modulating neuronal function in this region.

Local injection of rmIL-18 in the mouse adBST reduced food intake compared with vehicle for at least $6 \mathrm{~h}$ and reduced c-fos activation observed at refeeding upon food deprivation. These actions were observed at a dose of 0.3 $\mathrm{nmol} /$ mouse, or one-third of the minimal dose previously required to observe anorexigenic effects when rmIL-18 was injected intracerebroventricularly (Zorrilla et al., 2007). Also, consistent with what was observed after intracerebroventricular injections, administration of rmIL-18 in the adBST did not elicit other signs of sickness, including fever.

\section{IL-18 and neuronal functions}

To begin to understand how IL-18 altered neuronal function in the adBST, we measured the electrophysiological effects of IL-18 in adBST neurons. The adBST is a heterogeneous structure consisting of neurons with different electrophysiological, neurochemical, and anatomical connections (Daniel and Rainnie, 2016). Different functional types of GABAergic neurons (i.e., Type I, II, and III) can be identified by the presence and the amount of specific voltage-gated ionic conductances (Szücs et al., 2010, 2012; see also Rodríguez-Sierra et al., 2013). Type I and Type II neurons are sparsely distributed in the ovBST and the broader alBST (Daniel and Rainnie, 2016). In contrast, Type III neurons are densely packed in the jcBST. Many of these neurons express corticotropin-releasing factor (Dabrowska et al., 2011; Hazra et al., 2011) and project to the lateral hypothalamus, but not to the ventral tegmental area (Rodríguez-Sierra et al., 2013; Silberman et al., 2013).

In Type III jcBST neurons, IL-18 reduced the inward rectification mediated by the $\mathrm{I}_{\mathrm{KIR}}$, which has been demonstrated to participate in establishing the resting membrane potential (Hammack et al., 2007). Thus, the reduction of $I_{\text {KIR, }}$ together with other ionic currents, could contribute to the membrane depolarization induced by IL-18. Although the membrane depolarization moves the resting membrane potential closer to the voltage threshold, no spontaneous firing was generated. Moreover, the neuronal excitability was not altered as the slope of the I/O function was unchanged.
The rmIL-18 rapidly induced a strong reduction of the peak amplitude of eAMPA-EPSCs and a decrease in the frequency of mAMPA-EPSCs. These effects required IL- $18 \mathrm{R} \alpha$ because they were not found in Type III neurons from Ills $\mathrm{ra}^{-1-}$ mice.

Instead, IL-18 reduced the strength of excitatory synaptic transmission onto Type III jcBST neurons, as indicated by increases in the PPR and CV, via the activation of IL-18 receptors. Changes in PPR are generally observed following procedures that alter the probability of transmitter release (Zucker, 1989); they are less frequently associated with postsynaptic alterations (Clark et al., 1994). Together, increases in PPR and the CV, and decreases in the frequency of spontaneous, action potentialindependent AMPA-EPSCs without alteration in their mean amplitude, provide complementary evidence for the involvement of presynaptic mechanisms in the effects of IL-18 on Type III neurons (Malinow and Tsien, 1990; Bolshakov and Siegelbaum, 1994; Bekkers and Delaney, 2001). Previous studies demonstrated different effects of IL-18 and other interleukins in modulating synaptic neurotransmission and synaptic plasticity in other synaptic pathways (Tancredi et al., 2000; Curran et al., 2003; Stellwagen and Malenka, 2006; O'Connor, 2015). At glutamatergic synapses between CA3-derived Schaffer collateral fibers and CA1 hippocampal pyramidal neurons, IL-18 enhanced the evoked AMPA-mediated postsynaptic response by increasing presynaptic glutamate release (Kanno et al., 2004). This effect may increase the excitatory influence of CA1 pyramidal cells on their target neurons. In the jcBST, IL-18-mediated reduction of excitatory synaptic inputs to GABAergic Type III jcBST neurons may indirectly disinhibit their target LH neurons. IL-18 did not induce changes in the frequency of mAMPA-EPSCs recorded from Type I neurons. Because Type I neurons are located more medially with respect to Type III jcBST and receive significantly less mAMPA-EPSCs, we can only speculate that Type I neurons receive excitatory input from a distinct set of glutamatergic pro- 
jections that do not have IL-18R on their terminals. The molecular mechanisms of IL-18 action at the presynaptic level still need to be investigated.

In our study, we demonstrated that IL-18 induces a longlasting depolarization of Type III neurons to $\sim-50 \mathrm{mV}$, most likely by blocking KIR channels. Interestingly, KIR channels (Kir2.3 and Kir3.3) are also expressed on presynaptic terminals (Trimmer, 2015), and it has been shown that KIR channels located in the vicinity of the presynaptic active zone can participate in the regulation of neurotransmitter release (Aguado et al., 2008). Recently, it has been demonstrated that KIR conductance present on the presynaptic terminals of corticostriatal afferents regulates glutamate release at these synapses (Meneses et al., 2015). We suggest that long-lasting membrane depolarization of presynaptic glutamatergic terminals induced by IL- 18 can reduce the amplitude of the eAMPA-EPSCs through the voltagedependent inactivation of presynaptic calcium channels involved in the evoked glutamate release

In conclusion, collectively, our data show that IL-18 acts on the adBST to reduce food intake, and this behavioral effect may result from reduced excitatory drive of Type III GABAergic neurons in the jcBST. This model is consistent with recent findings that activation of GABAergic BST neurons projecting to glutamatergic LH neurons dramatically increases food intake (Jennings et al., 2013) and provides new insights into how a proinflammatory cytokine may contribute to a key component of "sickness syndrome" (loss of appetite) via receptor-specific modulation of central neuronal circuitry that modulates feeding. Whereas the IL-18 receptors IL-18R $\alpha$ and IL-18R $\beta$ are constitutively expressed in the BST and in other brain regions, cytokine levels in the normal healthy brain are typically low. However, IL-18 synthesis is strongly elevated in activated microglia as well as in ependymal cells and neurons of the medial habenula during stress (Culhane et al., 1998; Conti et al., 1999; Prinz and Hanisch, 1999; Sugama et al., 2002; Alboni et al., 2010). Thus, IL-18 and the BST may be important regulators of appetite during infection, illness, and certain types of stress/anxiety disorders and represent novel targets for cachexia and, perhaps, eating disorders and obesity.

\section{References}

Aguado C, Colon J, Ciruela F, Schlaudraff F, Cabanero MJ, Perry C, Watanabe M, Liss B, Wickman K, Lujan R (2008) Cell type-specific subunit composition of $\mathrm{G}$ protein-gated potassium channels in the cerebellum. J Neurochem 105:497-511. CrossRef Medline

Alboni S, Cervia D, Ross B, Montanari C, Gonzalez AS, Sánchez-Alavez M, Marcondes MC, De Vries D, Sugama S, Brunello N, Blom J, Tascedda F, Conti B (2009) Mapping of the full length and the truncated interleukin-18 receptor alpha in the mouse brain. J Neuroimmunol 214: 43-54. CrossRef Medline

Alboni S, Cervia D, Sugama S, Conti B (2010) Interleukin 18 in the CNS. J Neuroinflammation 7:9. CrossRef Medline

Alboni S, Montanari C, Benatti C, Blom JM, Simone ML, Brunello N, Caggia F, Guidotti G, Marcondes MC, Sánchez-Alavez M, Conti B, Tascedda F (2011) Constitutive and LPS-regulated expression of interleukin-18 receptor beta variants in the mouse brain. Brain Behav Immun 25:483-493. CrossRef Medline

Aston-Jones G, Druhan J (1999) Behavioural pharmacology: breaking the chain of addiction. Nature 400:317:319. CrossRef Medline

Bekkers JM, Delaney AJ (2001) Modulation of excitability by alphadendrotoxin-sensitive potassium channels in neocortical pyramidal neurons. J Neurosci 21:6553-6560. Medline

Bolshakov VY, Siegelbaum SA (1994) Postsynaptic induction and presynaptic expression of hippocampal long-term depression. Science 264: 1148-1152. CrossRef Medline

Choi S, Lovinger DM (1997) Decreased probability of neurotransmitter re- lease underlies striatal long-term depression and postnatal development of corticostriatal synapses. Proc Natl Acad Sci U S A 94:2665-2670. CrossRef Medline

Ciccocioppo R, Fedeli A, Economidou D, Policani F, Weiss F, Massi M (2003) The bed nucleus is a neuroanatomical substrate for the anorectic effect of corticotropin-releasing factor and for its reversal by nociceptin/ orphanin FQ. J Neurosci 23:9445-9451. Medline

Clark KA, Randall AD, Collingridge GL (1994) A comparison of pairedpulsed facilitation of AMPA and NMDA receptor-mediated excitatory postsynaptic currents in the hippocampus. Exp Brain Res 101:272-278. Medline

Conti B, Park LC, Calingasan NY, Kim Y, Kim H, Bae Y, Gibson GE, Joh TH (1999) Cultures of astrocytes and microglia express interleukin 18. Brain Res Mol Brain Res 67:46-52. CrossRef Medline

Culhane AC, Hall MD, Rothwell NJ, Luheshi GN (1998) Cloning of rat brain interleukin-18 cDNA. Mol Psychiatry 3:362-366. CrossRef Medline

Curran BP, Murray HJ, O'Connor JJ (2003) A role for c-Jun N-terminal kinase in the inhibition of long-term potentiation by interleukin-1beta and long-term depression in the rat dentate gyrus in vitro. Neuroscience 118:347-357. CrossRef Medline

Dabrowska J, Hazra R, Ahern TH, Guo JD, McDonald AJ, Mascagni F, Muller JF, Young LJ, Rainnie DG (2011) Neuroanatomical evidence for reciprocal regulation of the corticotrophin-releasing factor and oxytocin systems in the hypothalamus and the bed nucleus of the stria terminalis of the rat: implications for balancing stress and affect. Psychoneuroendocrinology 36:1312-1326. CrossRef Medline

Daniel SE, Rainnie DG (2016) Stress modulation of opposing circuits in the bed nucleus of the stria terminalis. Neuropsychopharmacology 41: 103-125. CrossRef Medline

Davis M, Walker DL, Miles L, Grillon C (2010) Phasic vs sustained fear in rats and humans: role of the extended amygdala in fear vs anxiety. Neuropsychopharmacology 35:105-135. CrossRef Medline

de Araujo IE, Rolls ET, Kringelbach ML, McGlone F, Phillips N (2003) Taste-olfactory convergence, and the representation of the pleasantness of flavour, in the human brain. Eur J Neurosci 18:2059-2068. CrossRef Medline

Dong H, Petrovich GD, Swanson LW (2000) Organization of projections from the juxtacapsular nucleus of the BST: a PHAL study in the rat. Brain Res 859:1-14. CrossRef Medline

Dong HW, Petrovich GD, Swanson LW (2001) Topography of projections from amygdala to bed nuclei of the stria terminalis. Brain Res Brain Res Rev 38:192-246. CrossRef Medline

Francesconi W, Berton F, Repunte-Canonigo V, Hagihara K, Thurbon D, Lekic D, Specio SE, Greenwell TN, Chen SA, Rice KC, Richardson HN, O'Dell LE, Zorrilla EP, Morales M, Koob GF, Sanna PP (2009) Protracted withdrawal from alcohol and drugs of abuse impairs long-term potentiation of intrinsic excitability in the juxtacapsular bed nucleus of the stria terminalis. J Neurosci 29:5389-5401. CrossRef Medline

Frank RL (1952) Psychoanalysis. Prog Neurol Psychiatry 7:499-510. Medline

Franklin K, Paxinos G (1997) The mouse brain in stereotaxic coordinates. San Diego: Academic.

Funk CK, O’Dell LE, Crawford EF, Koob GF (2006) Corticotropin-releasing factor within the central nucleus of the amygdala mediates enhanced ethanol self-administration in withdrawn, ethanol-dependent rats. J Neurosci 26:11324-11332. CrossRef Medline

Gafford GM, Ressler KJ (2015) GABA and NMDA receptors in CRF neurons have opposing effects in fear acquisition and anxiety in central amygdala vs. bed nucleus of the stria terminalis. Horm Behav 76:136-142. CrossRef Medline

Gafford GM, Guo JD, Flandreau EI, Hazra R, Rainnie DG, Ressler KJ (2012) Cell-type specific deletion of GABA(A)alphal in corticotropin-releasing factor-containing neurons enhances anxiety and disrupts fear extinction. Proc Natl Acad Sci U S A 109:16330-16335. CrossRef Medline

Georges F, Aston-Jones G (2001) Potent regulation of midbrain dopamine neurons by the bed nucleus of the stria terminalis. J Neurosci 21:RC160. Medline

Georges F, Aston-Jones G (2002) Activation of ventral tegmental area cells by the bed nucleus of the stria terminalis: a novel excitatory amino acid input to midbrain dopamine neurons. J Neurosci 22:5173-5187. Medline Hale MW, Spencer SJ, Conti B, Jasoni CL, Kent S, Radler ME, Reyes TM, 
Sominsky L (2015) Diet, behavior and immunity across the lifespan. Neurosci Biobehav Rev 58:46-62. CrossRef Medline

Hammack SE, Mania I, Rainnie DG (2007) Differential expression of intrinsic membrane currents in defined cell types of the anterolateral bed nucleus of the stria terminalis. J Neurophysiol 98:638-656. CrossRef Medline

Hazra R, Guo JD, Ryan SJ, Jasnow AM, Dabrowska J, Rainnie DG (2011) A transcriptomic analysis of Type I-III neurons in the bed nucleus of the stria terminalis. Mol Cell Neurosci 46:699-709. CrossRef Medline

Jalabert M, Aston-Jones G, Herzog E, Manzoni O, Georges F (2009) Role of the bed nucleus of the stria terminalis in the control of ventral tegmental area dopamine neurons. Prog Neuropsychopharmacol Biol Psychiatry 33:1336-1346. CrossRef Medline

Jennings JH, Rizzi G, Stamatakis AM, Ung RL, Stuber GD (2013) The inhibitory circuit architecture of the lateral hypothalamus orchestrates feeding. Science 341:1517-1521. CrossRef Medline

Kanno T, Nagata T, Yamamoto S, Okamura H, Nishizaki T (2004) Interleukin-18 stimulates synaptically released glutamate and enhances postsynaptic AMPA receptor responses in the CA1 region of mouse hippocampal slices. Brain Res 1012:190-193. CrossRef Medline

Kelley KW, Bluthe RM, Dantzer R, Zhou JH, Shen WH, Johnson RW, Broussard SR (2003) Cytokine-induced sickness behavior. Brain Behav Immun 17 [Suppl 1]:S112-S118.

Kim SY, Adhikari A, Lee SY, Marshel JH, Kim CK, Mallory CS, Lo M, Pak S, Mattis J, Lim BK, Malenka RC, Warden MR, Neve R, Tye KM, Deisseroth K (2013) Diverging neural pathways assemble a behavioural state from separable features in anxiety. Nature 496:219-223. CrossRef Medline

Konsman JP, Parnet P, Dantzer R (2002) Cytokine-induced sickness behaviour: mechanisms and implications. Trends Neurosci 25:154-159. CrossRef Medline

Larriva-Sahd J (2004) Juxtacapsular nucleus of the stria terminalis of the adult rat. Extrinsic inputs, cell types, and neuronal modules: a combined Golgi and electron microscopic study. J Comp Neurol 475:220-237. CrossRef Medline

Lee Y, Fitz S, Johnson PL, Shekhar A (2008) Repeated stimulation of CRF receptors in the BNST of rats selectively induces social but not panic-like anxiety. Neuropsychopharmacology 33:2586-2594. CrossRef Medline

Malinow R, Tsien RW (1990) Presynaptic enhancement shown by wholecell recordings of long-term potentiation in hippocampal slices. Nature 346:177-180. CrossRef Medline

Manabe T, Wyllie DJ, Perkel DJ, Nicoll RA (1993) Modulation of synaptic transmission and long-term potentiation: effects on paired pulse facilitation and EPSC variance in the CAl region of the hippocampus. J Neurophysiol 70:1451-1459. Medline

McDonald AJ (1983) Neurons of the bed nucleus of the stria terminalis: a Golgi study in the rat. Brain Res Bull 10:111-120. CrossRef Medline

McDonald AJ, Shammah-Lagnado SJ, Shi C, Davis M (1999) Cortical afferents to the extended amygdala. Ann N Y Acad Sci 877:309-338. CrossRef Medline

Meneses D, Mateos V, Islas G, Barral J (2015) G-protein-coupled inward rectifier potassium channels involved in corticostriatal presynaptic modulation. Synapse 69:446-452. CrossRef Medline

Micioni Di Bonaventura MV, Ciccocioppo R, Romano A, Bossert JM, Rice KC, Ubaldi M, St Laurent R, Gaetani S, Massi M, Shaham Y, Cifani C (2014) Role of bed nucleus of the stria terminalis corticotrophinreleasing factor receptors in frustration stress-induced binge-like palatable food consumption in female rats with a history of food restriction. J Neurosci 34:11316-11324. CrossRef Medline

Netea MG, Joosten LA, Lewis E, Jensen DR, Voshol PJ, Kullberg BJ, Tack CJ, van Krieken H, Kim SH, Stalenhoef AF, van de Loo FA, Verschueren I, Pulawa L, Akira S, Eckel RH, Dinarello CA, van den Berg W, van der Meer JW (2006) Deficiency of interleukin-18 in mice leads to hyperphagia, obesity and insulin resistance. Nat Med 12:650-656. CrossRef Medline

O'Connor JJ (2015) Neuroimmunology and synaptic function. Neuropharmacology 96:1-2. CrossRef Medline

Ohata H, Shibasaki T (2011) Involvement of CRF2 receptor in the brain regions in restraint-induced anorexia. Neuroreport 22:494-498. CrossRef Medline

Pelchat ML, Johnson A, Chan R, Valdez J, Ragland JD (2004) Images of desire: food-craving activation during fMRI. Neuroimage 23:1486-1493. CrossRef Medline
Poulin JF, Arbour D, Laforest S, Drolet G (2009) Neuroanatomical characterization of endogenous opioids in the bed nucleus of the stria terminalis. Prog Neuropsychopharmacol Biol Psychiatry 33:1356-1365. CrossRef Medline

Prinz M, Hanisch UK (1999) Murine microglial cells produce and respond to interleukin-18. J Neurochem 72:2215-2218. CrossRef Medline

Rodríguez-Sierra OE, Turesson HK, Pare D (2013) Contrasting distribution of physiological cell types in different regions of the bed nucleus of the stria terminalis. J Neurophysiol 110:2037-2049. CrossRef Medline

Sahuque LL, Kullberg EF, McGeehan AJ, Kinder JR, Hicks MP, Blanton MG, Janak PH, Olive MF (2006) Anxiogenic and aversive effects of corticotropin-releasing factor $(\mathrm{CRF})$ in the bed nucleus of the stria terminalis in the rat: role of CRF receptor subtypes. Psychopharmacology (Berl) 186:122-132. CrossRef Medline

Sánchez-Alavez M, Conti B, Moroncini G, Criado JR (2007) Contributions of neuronal prion protein on sleep recovery and stress response following sleep deprivation. Brain Res 1158:71-80. CrossRef Medline

Sánchez-Alavez M, Tabarean IV, Osborn O, Mitsukawa K, Schaefer J, Dubins J, Holmberg KH, Klein I, Klaus J, Gomez LF, Kolb H, Secrest J, Jochems J, Myashiro K, Buckley P, Hadcock JR, Eberwine J, Conti B, Bartfai T (2010) Insulin causes hyperthermia by direct inhibition of warmsensitive neurons. Diabetes 59:43-50. CrossRef Medline

Shepard JD, Schulkin J, Myers DA (2006) Chronically elevated corticosterone in the amygdala increases corticotropin releasing factor mRNA in the dorsolateral bed nucleus of stria terminalis following duress. Behav Brain Res 174:193-196. CrossRef Medline

Silberman Y, Matthews RT, Winder DG (2013) A corticotropin releasing factor pathway for ethanol regulation of the ventral tegmental area in the bed nucleus of the stria terminalis. J Neurosci 33:950-960. CrossRef Medline

Sink KS, Chung A, Ressler KJ, Davis M, Walker DL (2013) Anxiogenic effects of CGRP within the BNST may be mediated by CRF acting at BNST CRFR1 receptors. Behav Brain Res 243:286-293. CrossRef Medline

Small DM (2010) Taste representation in the human insula. Brain Struct Funct 214:551-561. CrossRef Medline

Stellwagen D, Malenka RC (2006) Synaptic scaling mediated by glial TNFalpha. Nature 440:1054-1059. CrossRef Medline

Storm JF (1988) Temporal integration by a slowly inactivating $\mathrm{K}^{+}$current in hippocampal neurons. Nature 336:379-381. CrossRef Medline

Sugama S, Cho BP, Baker H, Joh TH, Lucero J, Conti B (2002) Neurons of the superior nucleus of the medial habenula and ependymal cells express IL-18 in rat CNS. Brain Res 958:1-9. CrossRef Medline

Sun N, Cassell MD (1993) Intrinsic GABAergic neurons in the rat central extended amygdala. J Comp Neurol 330:381-404. CrossRef Medline

Szücs A, Berton F, Nowotny T, Sanna P, Francesconi W (2010) Consistency and diversity of spike dynamics in the neurons of bed nucleus of stria terminalis of the rat: a dynamic clamp study. PLoS One 5:e11920. CrossRef Medline

Szücs A, Berton F, Sanna PP, Francesconi W (2012) Excitability of jcBNST neurons is reduced in alcohol-dependent animals during protracted alcohol withdrawal. PLoS One 7:e42313. CrossRef Medline

Tancredi V, D'Antuono M, Cafè C, Giovedì S, Buè MC, D'Arcangelo G, Onofri F, Benfenati F (2000) The inhibitory effects of interleukin-6 on synaptic plasticity in the rat hippocampus are associated with an inhibition of mitogen-activated protein kinase ERK. J Neurochem 75:634-643. CrossRef Medline

Trimmer JS (2015) Subcellular localization of K+ channels in mammalian brain neurons: remarkable precision in the midst of extraordinary complexity. Neuron 85:238-256. CrossRef Medline

Zorrilla EP, Conti B (2014) Interleukin-18 null mutation increases weight and food intake and reduces energy expenditure and lipid substrate utilization in high-fat diet fed mice. Brain Behav Immun 37:45-53. CrossRef Medline

Zorrilla EP, Sánchez-Alavez M, Sugama S, Brennan M, Fernandez R, Bartfai $\mathrm{T}$, Conti B (2007) Interleukin-18 controls energy homeostasis by suppressing appetite and feed efficiency. Proc Natl Acad Sci U S A 104: 11097-11102. CrossRef Medline

Zucker RS (1989) Short-term synaptic plasticity. Annu Rev Neurosci 12: 13-31. CrossRef Medline 